\title{
THE DIFFERENT EFFECTS OF ZINC SUPPLEMENT AND VELVET BEAN MUCUNA PRURIENS EXTRACTS TOWARD FERTILITY OF BALBC/ MICE
}

\author{
Pardipta Pradipta Kurniasanti ${ }^{1}$, M. Zen Rahfiludin ${ }^{2}$, Sri Winarni ${ }^{3}$ \\ ${ }^{1}$ Faculty of Psychology and Health-Nutrition Science, Walisongo State Islamic University \\ ${ }^{2}$ Postgraduate Lecturer on Nutritional Sciences of Public Health Faculty, Diponegoro University \\ ${ }^{3}$ Lecturer on Biostatistics of Public Health Faculty, Diponegoro University \\ e-mail: dipta@walisongo.ac.id ${ }^{1}$
}

\begin{abstract}
Good quality velvet beans and zinc supplement are well studied and known as rich source of aphrodisiac. The following reseach was carried out to study the difference effect of zinc supplement (ZS) and velvet bean extracts (VBE) towards fertility of BALB/c mice i.e the number of sperm, the motility of sperm, the viability of sperm, the morphology of sperm, the existence of vagina plug, and the birth condition of mice. This study was an experiment using Posttest Only Controlled Group Design with three groups. The first group (A1) as control, the second group (A2) receives subcutaneous injection of 2methoxyethanol fraction as much as $200 \mathrm{mg} / \mathrm{kg}$ weight/day for 5 days, followed with ZS at a dosage of $0,026 \mathrm{mg} /$ day/head, and the third group (A3) receives subcutaneous injection of 2-methoxyethanol fraction as much as $200 \mathrm{mg} / \mathrm{kg}$ weight/day for 5 days, followed with VBE at a dosage of $56 \mathrm{mg} / \mathrm{kg}$ weight /day for 30 days. The quality of spermatozoa of A1, A2, and A3 was significant difference $(p<0.05)$. $B o t h$ of $A 2$ and $A 3$ were no significant difference of mean number of sperm $(p=0.274)$, mean percentage of sperm motility $(p=0.739)$, mean percentage of sperm viability $(p=0.141)$ and mean value of morphology of sperm $(p=0.394)$. The quality of spermatozoa and the total number of baby mice lived and died of $A 1, A 2$ and $A 3$ were significant difference. In addition, there was no significant difference in the existence of female mice's vaginal plug of $A 1, A 2$ and $A 3$. This study showed that ZS and VBE can increase the quality of spermatozoa of $B A L B / C$ mice.
\end{abstract}

Keywords: zinc supplement, velvet bean extracts, fertility, spermatozoa of mice.

\section{INTRODUCTION}

Infertility case has been a world issue (Sardjono et al., 2016; Martinez et al., 2012; Mathur, 2009). A review study showed a significant decrease in mean sperm count from 113 x 106 per $\mathrm{ml}$ in 1940 to $66 \times 106$ per $\mathrm{ml}$ in 1990 (Carlsen et al., 1992). In Australia, 1 out of 20 males has infertility problem and $50 \%$ of all infertility problem are associated with male (McLahlan et al., 2001). Infertility increases 15$20 \%$ from approximately 50 million couples in Indonesia. This infertility is consecutively caused by male ( $40 \%$ ) and female ( $40 \%)$, both of female and male $(10 \%)$, and another $10 \%$ of unidentified reasons. It means that the number of infertility increases in the last 50 years (Sardjono et al., 2016).
Various types of modern medicine have been applied to solve this case but many of which yield negative effects (Hart, 2005).

Zinc supplement is one of the essential micronutrients to increase the number, quality and motility of sperm for low fertility in men. Zinc within normal amount in male body will support reproduction system. Zinc supplementation at a dose of $0,026 \mathrm{mg} / \mathrm{day} / \mathrm{head}$ turns out to be optimal and shows a significant increase on the number and motility of sperm in mice (Widya, 2012). Zinc supplement can reduce reproduction potential of mice dosage dependently by affecting proliferation of spermatogonia (Sedigh et al., 2016). In addition to zinc supplement, $96 \%$ ethanol fractions and isolated velvet bean on quality of male mice spermatozoa are exposed to 2- methoxyethanol with a dose of $56 \mathrm{mg} / \mathrm{kg} /$ day. 
It improves the number, motility rate, and the percentage of spermatozoa viability and the percentage of normal sperm morphology (Winarni, 2010). Various study had be done to investigate the aphrodisiac activity of velvet bean extracts (Gupta et al., 2011; Sukhla et al., 2010; Sekar et al., 2009; Ahmad et al., 2008). Therefore the following research was carried out to compare the difference effect of zinc supplement and velvet bean extracts toward fertility of BALB/c mice.

Materials and Methods Zinc supplement (ZS) Zinc supplement was a syrup (Zinkid) purchased from the clinic of pharmacy, then the dosage was diluted up to $0.026 \mathrm{mg} /$ day/head. Source of 2-methoxyethanol The toxic of 2methoxyethanol fraction as much as $200 \mathrm{mg} / \mathrm{kg}$ weight/day were purchased from (collection of Mrs. Hayati) Biological Laboratory of Unair, Surabaya, Indonesia.

Velvet bean extracts (VBE) preparation Velvet beans were sun dried to reduce water content and shelled to obtain the seed (nib). Nib was defatted by maceration with $1500 \mathrm{ml}$ aceton and shaked for $48 \mathrm{~h}$ at room temperature. It was filtered, then filtrate of velvet powder was extracted by maceration with water and $96 \%$ ethanol (1:1) (sample to solvent ratio of $1: 2 \mathrm{w} / \mathrm{v}$ )). The extraction process was carried out for $24 \mathrm{~h}$ at room temperature $\left(25^{\circ} \mathrm{C}\right)$. Once the extraction was complete, it was filtered by vacuum (Winarni, 2010). The resulting velvet bean extracts was condensed by a rotary evaporator at $40^{\circ} \mathrm{C}, 50 \mathrm{rpm}$ and dried by vacuum oven and designed as velvet bean extracts (VBE).

\section{MATERIAL AND METHODS}

\section{Animal}

The kind of rat was the BALB/c mice strain Mus Muculus obtained from the Biological Laboratory of Universitas Negeri Semarang (UNNES), Indonesia.

\section{Preparation of laboratory experimental and control research}

The number of mice used for all three groups were $45 \mathrm{BALB} / \mathrm{c}$ male mice $(8 \mathrm{w}$ old, weighing about 20-30 $\mathrm{g}$ were used for the investigation). The ratio of $\mathrm{BALB} / \mathrm{c}$ female mice and $\mathrm{BALB} / \mathrm{c}$ male mice was $1: 2$ each group. It means that a male mice was mated with 2 female mices, and 15 mices of each group (9 mices were examined its sperm quality, 6 mices were mated).

\section{Monitoring of the existence of vaginal plug}

Male and female mice were mated in a week. Every morning for a week, the female mice examined whether there was vagina plug with the use of apusan vagina. When vagina plug was found in red colour, it indicates that intercouse was done. It was defined as the first day of female mice pregnancy (Adnan, 2006).

\section{The number of sperm}

Neck-dislocated died mice were located on tray for surgery. Their cauda epididymis was isolated using $\mathrm{NaCl}$. Sperm liquid was emptied from cauda epididymis by a syringe before it was dissolved with $2 \mathrm{ml} \mathrm{NaCl}$ until it became homogenous. The calculation of the sperm concentration was using haemacytometer improved neubauer before it was observed by a microscope of $400 x$ magnifications. The calculation was conducted for four boxes of counting chamber, prior to average calculation. The result of the calculation was the sperm concentration in 10-4 ml sperm suspension (Hayati, 2007):

Number of cell $/ \mathrm{ml}=$ number of spermatozoa (n) $\mathrm{x}$ $104 \mathrm{x}$ dilution factor

Sperm motility was observable from sperm suspension dropped on neubauer counting chamber observed by a microscope of 400x magnifications. Sperm motility was valued on the basis of percentage of good sperm motility, that was sperm 
which moves fast, straight forward and active (Aleissa, 2014).

The percentage of sperm motility was measured by the following equation (Goyal et al., 2001; Hayati, 2007; Canyurt and Akhan, 2008): Spermatozoa motility $(\%)=$ category A + B x $100 \%$ $\underline{100}$ : spermatozoa.

\section{The viability of sperm}

Sperm viability was observable from sperm suspension dropped on colouring eosin Y $1 \%$ observed by a microscope of 400x magnifications. Sperm viability was valued on the basis of percentage of good sperm viability. That was sperm which indicates transparant color as live and red color as die (Aleissa, 2014).

The percentage of sperm viability was measured by the following equation (Goyal et al., 2001; Hayati, 2007; Canyurt and Akhan, 2008): Spermatozoa viability $(\%)=$ I spermatozoa The morphology of sperm

Sperm morphology testing was conducted by differentiating the shape of normal and abnormal sperm of 100 sperms observed before it was made into percentage (Aleissa, 2014). Abnormal sperm includes abnormality such as broken, detached and thin head; broken, crooked and droplet cytoplasm middle part or broke, crooked and coil tail. The observation used a microscope of $400 x$ magnifications (Henderson and Robaire, 2005; Sardjono et al., 2016).

\section{Analysis of the data}

Results were expressed as mean $\pm \mathrm{SD}$. The normality of the data was tested using Shapiro Wilks. Statistical test uses Kruskal-Wallis Test, Mann- Whitney test, One-way ANOVA test, and followed by Post Hoc LSD test, with the significant level of 0.05 .

\section{RESULTS AND DISCUSSIONS}

\section{The number of sperm}

The mean number of sperm of A2 (3.29 \pm 0.55 million $/ \mathrm{ml})$ and A3 $(3.66 \pm 0.99$ million $/ \mathrm{ml})$ were greater than A1 $(2.67 \pm 0.37$ million $/ \mathrm{ml})$ (Figure 1a). It indicated that higher number of sperm in A2 and A3 also gave a stronger spermatogenesis activity, whereas ZS and VBE have aphrodisiac content to increase the number of sperm. This is in line with the general knowledge that ZS can increase the number of sperm stem cells (Sedigh et al., 2016) and VBE can increase the number of sperm with stimulating the hormones of mice (Sardjono et al., 2016).

There was a significant difference of the number of sperm of A1, A2 and A3 by ANOVA Test $(p=0.019)$, whereas LSD test showed the significant difference of A1 versus A3 $(p=0.006)$ and A1 versus A2 $(p=0.069)$ respectively. However, there was no significant difference of A2 versus $A 3(p=0.274)$. This fact proved that the $Z S$ and VBE were the same effect that affected the number of sperm of the mice. Thus, ZS and VBE are a powerful source of aphrodisiac food which is potential to increase the number of sperm.

\section{The motility of sperm}

The mean percentage of sperm motility in A2 $(77.7 \pm 12.0 \%)$ and $\mathrm{A} 3(79.4 \% \pm 7.7 \%)$ were greater than A1 (54.4 $\pm 11.3 \%)$ (Figure 1b). It indicated that higher motility of sperm affected by the number of sperm and morphology of sperm. A living spermatozoa correlates highly to the motility of the sperm as being alive is an absolute requirement for a spermatozoa to be able to produce energy and move. Semen of mammal that has high fertility is characterized with a high level of living spermatozoa with normal morphology. Good motility depends on many things, including the morphology of sperm (Sardjono et al., 2016). 
There was a significant difference of the percentage of sperm motility of A1, A2 and A3 by ANOVA Test $(p=0.001)$, whereas LSD test showed the significant difference of the percentage of sperm motility of $A 1$ versus $A 2(p=0.001)$ and A1 versus A3 $(p=0.001)$ respectively. However, there was no significant difference of $A 2$ versus $A 3$ $(p=0.739)$. This fact proved that the ZS and VBE were the same effect that affected the motility of sperm of the mice too. It given correlates positively with the previous result and discussion (the number of sperm). A large amount of sperm with good sperm motility is sufficient for the insemination to take place successfully.

\section{The viability of sperm}

The mean percentage of sperm viability in A2 $(29.0 \pm 3.2 \%)$ and A3 $(31.3 \pm 3.7 \%)$ were greater than $\mathrm{A} 1(17.4 \pm 2.8 \%)$ (Figure 1c). There was a significant difference of the percentage of sperm viability of A1, A2 and A3 by ANOVA Test $(\mathrm{p}=0.001)$. LSD test showed showed the significant difference of the percentage of sperm viability of $A 1$ versus $A 2(p=0.001)$ and $A 1$ versus $\mathrm{A} 3(\mathrm{p}=0.001)$ respectively. However, there was no significant difference of $A 2$ versus A3 $(p=0.141)$. The study shows that ZS and VBE can increase the viability of sperm as well as increase the number of sperm and the motility of sperm. This increase in viability sperm is inseparable from L-dopa component found in VBE. This compound not only increase sexual activity but also hormones regulating spermatogonia process such as FSH and LH (Sardjono et al., 2016). Whereas ZS concentration in seminal plasma is known to correlate with the viability of sperm (Akinloye et al., 2011; Colagar et al., 2009).

\section{The morphology of sperm}

The morphology of sperm of A2 (19.4 \pm $3.2 \%)$ and $\mathrm{A} 3(21.6 \pm 5.2 \%)$ was greater than $\mathrm{A} 1$ $(13.3 \pm 3.5 \%)$. There was no significant difference of the morphology of sperm of A1, A2, and A3 by Kruskal-Wallis test $(p=0.003)$. When A1 was compared to A2 and A3, it showed the significant difference of the morphology of sperm by MannWhitney Test $(p<0.05)$. It means the existence of ZS in A2 and VBE in A3 affected the normality of morphological sperm of BALB/c mice. This is in line with the general knowledge that VBE treatment succeeded in reducing morphological abnormal sperm in all dosage given $(50,100,150$, 200 and $250 \mathrm{mg} / \mathrm{kg}$ (Sardjono et al., 2016), which is our study use dosage of $\mathrm{VBE}$ as much as 56 $\mathrm{mg} / \mathrm{kg}$. However, there was no significant difference of A2 versus A3 ( $p>0.05$ ) (Table 1). Increased number of sperm and motility of sperm as well as decreased abnormal sperm morphology of mice occur because of L-dopa and other components contained in VBE which influence the secretion of testosterone (Sardjono et al., 2016). Whereas ZS plays key role in immune system improvement and activity of hormones to affect spermatogonia process and the effects of ZS on prostate gland are very obvious (Sedigh et al., 2016).

\section{The existence of vagina plug}

Male mice in A1, A2, and A3 had the same capability to impregnate female mice. Overall our study showed that only one female mice in each group had no vagina plug. It means there was one male mice able to mate two female mices, but other male mice only one female mice.

\section{The birth condition of mice}

The ratio number of baby mice dead in A1 $(0.22)$ was two among nine $(18 \% ; 7$ alive out of 39 babies born), A2 (0.26) was five baby mices dead out of 19 (36\%; 14 alive out of 39 babies born) and A3 (0.18) was four baby mices dead out of 22 (46\%; 18 alive out of 39 babies born) (Figure 2). It showed that female mice given ZS and VBE produced more baby mice than control group. It 
was likely due to mineral of zinc contained in VBE and also other vitamins and minerals. This result given correlation positively with the quality of spermatozoa. Our study showed that ZS and VBE increase the number, motility, viability, and morphology of sperm. Fertility amount was increased by ZS and VBE, which is due to intensive increasing in epididymis sperms. Since certain number of sperm in the semen was necessary for fertilization. This increasing will directly affect the number of fertilized ovules of female mice.

The mean weight of baby mice in A2 $(0.55 \pm 0.13$ g) and A3 (053 $\pm 0.14 \mathrm{~g})$ was greater than A1 (0.49 $\pm 0.12 \mathrm{~g}$ ) (Figure 3). There was no significant difference of the weight of baby mice by ANOVA Test $(p=0.644)$ and LSD Test $(p>0.05)$

\section{CONCLUSIONS}

Zinc supplement and velvet bean extracts increase the quality of spermatozoa (the number of sperm, the motility of sperm, the viability of sperm and the morphology of sperm) of BALB/c mice higher than control group and can be used as aphrodisiac food.

\section{ACKNOWLEDGEMENT}

The author acknowledge the co-author (Mr. Prayoga and Mr. Rahfiludin) and family of Master Program in Nutrition-Food Concentration, Diponegoro University, Semarang, Indonesia

\section{REFERENCES}

Adnan. 2006. Reproduction and Embryology. Departemen Biologi Universitas Negeri Makassar. Makassar.

Ahmad, M.K., Mahdi, A.A., Shukla, K.K., Islam, N., Jaiswar, S.P. and Ahmad, S. 2008. Effect of Mucuna pruriens on Semen Profile and Biochemical Parameter in Seminal Plasma of Infertile Men. 90:3.
Akinloye, O., Abbiyesuku, F.M., Oguntibeju, O.O., Arowojolu, A.O. and Truter, E.J. 2011. The Impact of Blood and Seminal Plasma Zinc and Copper Concentrations on Spermogram and Hormonal Changes in Infertile Nigerian Men. Reproductiove Biology, 11:83-98.

Aleissa, M.S. 2014. Effect of Ginger Supplements on Some Reproductive Parameters and Spermatogenesis of Mice. J Life Sci 4:271427.

Canyurt, M.A. and Akhan, S. 2008. Effect of Ascorbic Acid Supplementation on Sperm Quality of Rainbow Trout (Onchorynchus mykiss). J Fisheries Aquat Sci 8: 171-175

Carlsen, E., Giwercman, A., Keiding, N. and Skakkebaek, N.E. 1992. Evidence for Decreasing Quality of Semen During Past 50 y. Br Med J 305:609-13.

Colagar, A.H., Marzony, E.T. and Chalci, M.J. 2009. Zinc Levels in Seminal Plasma are Associated with Sperm Quality in Fertile and infertile Men. Nutrition Research, 29:82-88.

Goyal, H.O. and Braden, T.D. 2001. Diethylstilbestrol -treated adult rats with altered apididymal sperm numbers and sperm motility parameters but without alteration in sperm production and sperm morphology, Biology of Reproduction, 927934

Gupta, A., Ahmad, M.K., Mahdi, A.A., Shukla, K.K., Bansal, N., Jaiswar, S.P. and Shankhwar, S.N. 2011. A Proton NMR Study of The Effect of Mucuna pruriens on Seminal Plasma Metabolites of Infertile Males. J Pharm Biomed Anal 55: 1060-1066.

Hart, B.L. 2005. The Evolution of Herbal Medicine: Behavioural Perspective. Anim Behav 70:975-989.

Hayati A. 2007. Spermatology. Fakultas Biologi Universitas Airlangga. Surabaya.

Henderson and Robaire. 2005. Effect of PNU157706, A Dual 5 $\alpha$-reductase inhibitor, 
on Rat Epididymal Sperm Maturation and Fertility. Biological of Reproduction, 72: 436-443.

Martinez, G., Daniels, K. and Chandra, A. 2012. Fertility of men and women aged 15-44 y in the United States: National Survey of Family Growth 2006-2010. Natl Health Stat Rep 51: 1-8.

Mathur, M. and Sundaramoorthy, S. 2009. Plants with Aphrodisiac Potential- The Knowledge and The Gaps. Indian Medicinal Plants. Aavishkar Publisher. Jaipur.

McLahlan, R. and de Krester, D. 2001. Male Infertility: The Case for Continued Research. Med J Aust 174:116-117.

Sardjono, R.E., Pradipta, V. and Mustapha, I. 2016. The Effect of Indonesian Velvet Bean Extract on The Fertility of Albino Male Mice. Int J Pharm Pharm Sci 8(8): 103-106.

Sedigh, A., Modaresi, M. and Pirestani, A. 2016. The Effects of Zinc Supplement on Fertility in Male Mice. Journal of Chem and Pharm Research 8(1): 66-70.

Sekar, S., Elumalai, P. and Seppan, P. 2009. Doseand Time-Dependent Effects of Ethanolic Extract of Mucuna pruriens Linn. Seed on Sexual Behaviour of Normal Male Rats. Journal of Ethnopharmacol, 122: 497- 501.

Shukla, K.K., Ahmad, M.K., Mahdi, A.A., Shankhwar, S.N., Jaiswar, S.P. and Tiwari, S.C. 2010. "Mucuna pruriens Reduces Stress and Improves the Quality of Semen in Infertile Men" Evid Based Complement Alternat Med, 7(1): 137-144

Widya, F. 2012. Giving effect Supplementation Zinc (Zn) to Total and Sperm Motility mice (Mus musculus) Balb/c males. Thesis. Fakultas Ilmu Gizi. Universitas Diponegoro. Semarang

Winarni, S. 2010. Pengaruh Fraksi Etanol 96\% dan Isolat Biji Koro Benguk (Mucuna pruriens) terhadap Kualitas Spermatozoa Mencit (Mus
Muculus) terpapar 2-metoksi etanol. Tesis. Universitas Airlangga. Surabaya. 